\title{
Fate of fish production in a seasonally flooded saltmarsh
}

\author{
Philip W. Stevens ${ }^{1,2,3, *}$, Clay L. Montague ${ }^{1}$, Kenneth J. Sulak ${ }^{2}$ \\ ${ }^{1}$ Department of Environmental Engineering Sciences, University of Florida, PO Box 116450, Gainesville, \\ Florida 32611-6450, USA \\ ${ }^{2}$ Center for Aquatic Resource Studies, US Geological Survey, 7920 NW 71 St, Gainesville, Florida 32653, USA \\ ${ }^{3}$ Present address: Florida Fish and Wildlife Conservation Commission, Fish and Wildlife Research Institute, \\ 1481 Market Circle, Port Charlotte, Florida 33953, USA
}

\begin{abstract}
Although saltmarshes are thought to enhance the productivity of open estuarine waters, the mechanism by which energy transfer occurs has been debated for decades. One possible mechanism is the transfer of saltmarsh production to estuarine waters by vagile fishes and invertebrates. Monthly estimates of fish standing stock, net fish ingress, and predation were used to develop a biomass budget to estimate annual production of fishes and the relative yield to predatory fish, birds, and direct migration to the estuary. Annual production of saltmarsh fishes was estimated to be $31.0 \mathrm{~g}$ $\mathrm{m}^{-2}$ saltmarsh, which falls within the range of previously reported values for estuarine fish communities. The relative yields were 12 to $20 \%$ to piscivorous fishes, 8 to $13 \%$ to piscivorous birds, and 18 to

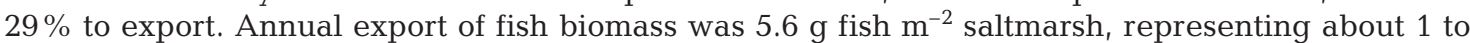
$2 \%$ of saltmarsh primary production. Saltmarsh fishes convert marsh production to high-quality vagile biomass (fishes concentrate energy, protein, and nutrients as body mass) and move this readily useable production to the estuary, providing an efficient link between saltmarshes and estuarine predators.
\end{abstract}

KEY WORDS: Saltmarsh impoundment · Outwelling hypothesis · Trophic relay • Wading birds

\section{INTRODUCTION}

Saltmarshes are among the most productive ecosystems in the world (Day et al. 1989, Montague \& Wiegert 1990, Mitsch \& Gosselink 1993, Montague \& Odum 1997), and, although they are thought to enhance the productivity of open estuarine waters, the mechanism by which energy transfer occurs has been debated for decades (Haines 1979, Nixon 1980, Dame 1994). Historically, saltmarshes were thought to contribute to estuarine productivity by exporting large quantities of detritus, which then formed the base of the estuarine food web (Teal 1962, Odum \& de la Cruz 1967, Wiegert et al. 1975). However, detrital and dissolved organic export from saltmarshes is variable among locations and is often only a minor contribution to estuarine productivity (Heinle \& Flemer 1976, Marinucci 1982, Borey et al. 1983, Montague et al. 1987 ,
Dame et al. 1991, Williams et al. 1992, Taylor \& Allanson 1995). Saltmarshes were also thought to supply nutrients to estuarine waters, thereby enhancing estuarine primary production (i.e. phytoplankton production). However, the majority of nutrients contained within saltmarsh plant tissues are recycled within the marsh and little is directly exchanged with the estuary relative to demand in estuarine waters (Haines et al. 1977, Valiela \& Teal 1979, Nixon 1980, Hopkinson \& Schubauer 1984).

Marsh sediments and their associated microbial communities can be sources or sinks for nutrients depending on the nutrient supply from other sources such as river discharge, upland runoff, and sewage effluent (Haines et al. 1977, Kaplan et al. 1979, Valiela $\&$ Teal 1979). For example, marshes with high input of nitrogen (the limiting nutrient in many estuaries) are likely to be sites of net denitrification, whereas 
marshes with low input of nitrogen are likely to be sites of net nitrogen fixation (Haines et al. 1977, Kaplan et al. 1979, Valiela \& Teal 1979, Montague et al. 1987). Although the historical paradigm of saltmarshes supplying detritus and nutrients directly to open estuarine waters remains equivocal, an alternative paradigm has been emerging that emphasizes the role of saltmarshes in providing food and refuge to young estuarine nekton and the role of nekton in transferring saltmarsh production to estuarine waters (Haines 1979, Haines \& Montague 1979, Montague et al. 1981, 1987, Werme 1981, Boesch \& Turner 1984, Knieb 1997).

Kneib (1997) described the movement of energy across the marsh landscape to the estuary via predator-prey relationships as 'the trophic relay' and developed a detailed conceptual model of these interactions. Resident nekton (those species that complete their life history within marshes) convert saltmarsh production into vagile biomass, which then may move across the marsh landscape as smaller residents are consumed by larger residents. The larger residents are more likely to move to subtidal creeks or seagrass beds during low water to escape desiccation or thermal stress on the marsh surface, which makes them susceptible to predation by young transient nekton (those species that use marshes periodically for food and refuge). The latter may move to deeper estuarine waters as they mature, or may be eaten by larger adult transients that occasionally foray into marsh creeks seeking prey. Non-predatory transient nekton (e.g. herrings, silversides, and mullets) also convert marsh foods into vagile biomass when present in the marsh as juveniles. They may be consumed by larger predatory transients during their residence within the marsh, or eventually emigrate to the open estuary as they reach maturity, moving the incorporated marsh resources with them.

The migrations involved in the 'trophic relay' occur at different spatial and temporal scales (Kneib 1997). For example, daily intertidal migrations occur as resident nekton move between marsh surface and creek habitats, or transient nekton move in and out of marsh creeks. In addition, seasonal migrations occur as larval and early juvenile stages move into marshes and later emigrate to the open estuary, and, in some cases, the open ocean. The interspecific interactions between resident marsh fishes and transient predators that occur within the marsh may be important mechanisms for moving the marsh resources that have been incorporated into resident nekton to the adjacent estuary.

Despite the potential importance of nekton in energy transfer from the marsh to the estuary, few studies have estimated saltmarsh nekton production (Welsh 1975, Valiela et al. 1977, Meredith \& Lotrich 1979, Schooley 1980, Weinstein 1983) or emigration (Herke et al. 1992, Deegan 1993), and none have measured these components simultaneously. The boundaries of saltmarsh systems are open and ill defined, and the conduits of transport (i.e. creeks) are broad and complex. Thus, estimating the boundaries within which production has occurred and measuring the exchange of nekton between saltmarshes and the estuary create difficult challenges with respect to sampling.

In east-central Florida, saltmarsh impoundments that have been reconnected to the estuary by culverts provide unique research opportunities that enable the estimation of both saltmarsh fish production and exchange rates of nekton with the estuary (for a history of impoundment construction, management strategies, and recent reconnection efforts see Brockmeyer et al. 1997). The boundaries between saltmarshes and the estuary are clearly defined by a system of dikes, thereby confining nekton into a known area, and the exchange of aquatic organisms is restricted to culverts. Open culverts allow sampling of nekton as they move between saltmarshes and the adjacent estuary. Where culverts are left open year-round, these nekton movements are driven by a strong seasonal component reflective of the hydrology of the northern Indian River Lagoon (Stevens et al. 2006). Thus, marsh to estuary fish movements occur on the order of months, not hours as in tidal marshes, and may therefore be easier to track over the course of a year. Although impoundments differ morphologically from natural systems, understanding the function of reconnected impoundments should provide a general model of saltmarsh ecology and linkages to the adjacent estuary by movement of aquatic organisms.

The artificial boundaries, creeks, and connections to the estuary, together with the seasonal hydrology associated with reconnected saltmarsh impoundments in the northern Indian River Lagoon, permit a biomass budget of saltmarsh fishes to be constructed (Fig. 1). Outputs from the standing stock of fish within the impoundment are the result of emigration and predation/death. Inputs to the standing stock of fish within the impoundment are the result of immigration and production. Monthly estimates of standing stock, immigration, emigration, and predation can be used to estimate annual production of fishes in the saltmarsh (Fig. 1). This estimate of saltmarsh fish production can be compared to estimates from other locations and other estuarine habitats, such as seagrass beds and open estuarine waters. More importantly, the yield to predatory fish, birds, and emigration can be quantified. The objective of the present study was to estimate the annual production of fishes in a seasonally flooded saltmarsh in the Indian River Lagoon, Florida (i.e. reconnected impoundment) and to quantify the relative yield to predatory fish, birds, and direct migration to the estuary. 


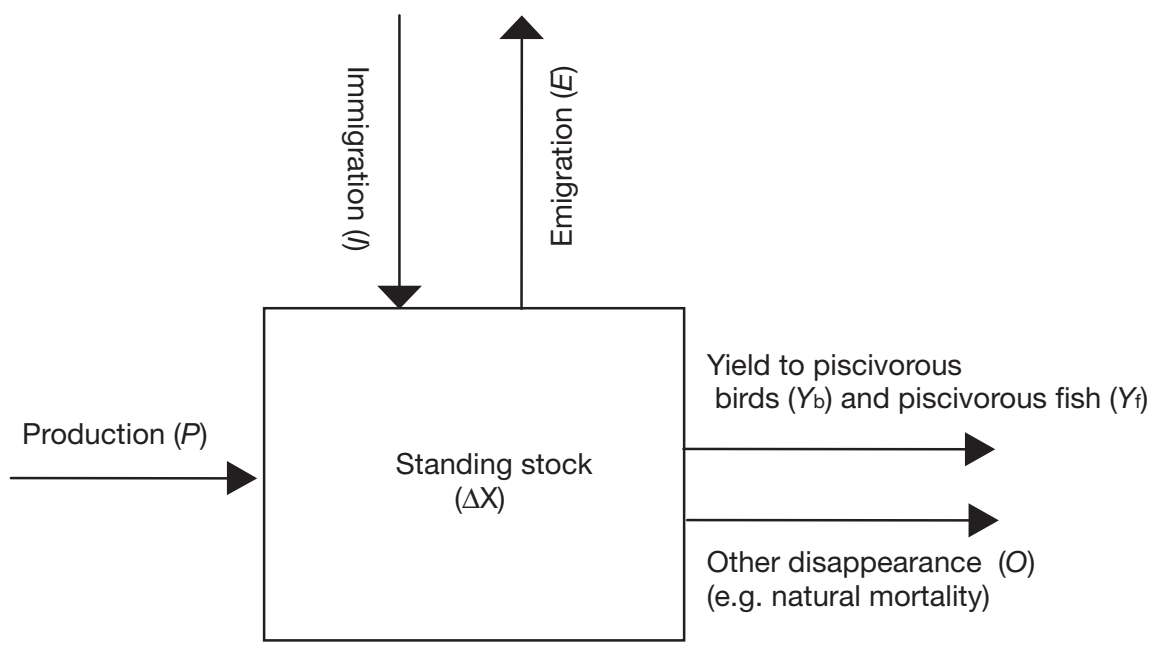

Fig. 1. Nekton biomass budget in a saltmarsh impoundment. Let net fish ingress $(M)=I-E$, and $P=\Delta X / \Delta$ time $+Y_{\mathrm{b}}+Y_{\mathrm{f}}+O-M$
(2006), and are summarized in the following subsection. Monthly impoundment fish densities were substituted into the above equations to estimate annual fish production. This fish production estimate can be compared to that developed in a biomass budget (see following subsection) in the same study impoundment, and to other studies that used Ricker's method.

Fish production estimate from biomass budget. The fish production estimate derived from Ricker's equations lumps population changes due to migration and mortality into a single variable $(Z)$. The unique research opportunities provided by impoundments (dikes confine fishes into a known area and exchange of fishes are restricted to culverts), however,

\section{MATERIALS AND METHODS}

Fish production estimates from Ricker's equations. Numerous studies have estimated fish production from equations based on Ricker (1946) as modified by Allen (1950) (a list of such studies is given in Day et al. 1989 and Chapman 1978). The only data needed for these equations are changes (usually monthly) in fish standing stock (number and biomass). The basic equations are: $P=G \times B$, where $G=\left(\ln w_{2}-\ln w_{1}\right) / \Delta t$ is the instantaneous coefficient of growth; $B=B_{1}\left(\mathrm{e}^{G-Z}-1\right) /(G-Z)$ is the average biomass; $Z=-\left(\ln N_{1}-\ln N_{2}\right) / \Delta t$ is the instantaneous coefficient of population change attributable to mortality and migration; $w_{1}$ and $w_{2}$ are the mean weights of individuals at time $t_{1}$ and $t_{2}$, respectively; and $N_{1}$ and $N_{2}$ are the number of fish present at time $t_{1}$ and $t_{2}$, respectively.

The model assumes that correction for immigration and emigration of fishes is not needed provided that fish density and size-class-specific growth are estimated often enough to assess abundance and growth of fishes in the sampling area during each sampling period (Chapman 1978). Monthly fish densities from Stevens et al. (2006) were used as basis data to estimate fish production in a reconnected saltmarsh impoundment (dominated by Distichlis spicata and Paspalum vaginatum) in Banana Creek, east-central Florida (Table 1). Detailed descriptions of the study site and sampling methods can be found in Stevens et al.
Table 1. Estimates of monthly fish standing stock (July 2000 to July 2001), net fish ingress, and piscivorous fish abundance within Impoundment C20C. Data are from Stevens et al. (2006). Fish standing stock was measured by cast net, net fish ingress was measured by culvert traps, and piscivorous fish abundance was measured by gill nets

\begin{tabular}{|c|c|c|c|c|c|c|}
\hline & \multicolumn{4}{|c|}{ Standing stock } & \multirow{2}{*}{$\begin{array}{c}\text { Ingress } \\
\text { (g fish per } \\
\text { culvert } \mathrm{h}^{-1} \text { ) }\end{array}$} & \multirow{2}{*}{$\begin{array}{c}\text { Abundance } \\
\text { (g piscivorous fish } \\
\text { per } 10 \mathrm{~m}^{-1} \mathrm{~h}^{-1} \text { ) }\end{array}$} \\
\hline & $\begin{array}{l}\text { Creek } \\
\text { (no. of } \mathrm{f}\end{array}$ & $\begin{array}{c}\text { Ditch } \\
h^{-2} \text { m }^{-2}\end{array}$ & $\begin{array}{r}\text { Creek } \\
\text { (g fis }\end{array}$ & $\begin{array}{l}\text { Ditch } \\
\left.\mathrm{m}^{-2}\right)\end{array}$ & & \\
\hline Jul & 0.1 & 0.2 & 0.6 & 2.2 & 15.6 & 1173 \\
\hline Aug & 0.5 & 1.5 & 3.4 & 3.5 & -3.1 & 1204 \\
\hline Sep & 0.0 & 0.2 & 0.0 & 0.2 & 0.3 & 9552 \\
\hline Oct & 0.1 & 0.2 & 0.5 & 2.7 & -8.1 & 2121 \\
\hline Nov & 0.3 & 0.5 & 0.1 & 1.8 & 0.0 & 1278 \\
\hline Dec & 3.8 & 23.0 & 5.6 & 16.9 & -6.0 & 3166 \\
\hline Jan & 12.6 & 57.8 & 11.6 & 38.5 & -25.3 & 2262 \\
\hline Feb & 11.4 & 9.1 & 16.0 & 16.2 & -11.5 & 736 \\
\hline Mar & 1.3 & 6.3 & 2.0 & 6.5 & -6.3 & 1367 \\
\hline Apr & 5.4 & 3.7 & 9.2 & 6.6 & -3.2 & 6962 \\
\hline May & 18.2 & 1.3 & 20.0 & 2.6 & -0.8 & 635 \\
\hline Jun & 2.7 & 3.0 & 8.4 & 9.6 & -13.2 & 14225 \\
\hline Jul & 19.4 & 2.5 & 32.8 & 6.7 & & \\
\hline
\end{tabular}


al. (2006). In summary, fish density (comprising mostly resident saltmarsh fishes such as Cyprinodon variegatus and Poecilia latipinna) was measured by cast net, both in a marsh creek and in a ditch (borrow ditch for impoundment dikes) that surrounds the perimeter of the marsh. Fourteen sites for cast-net deployment were randomly selected, in both the impoundment ditch and the creek for each monthly sampling. Immigration and emigration through impoundment culverts was measured for 4 days and 4 nights consecutively with culvert traps. A culvert trap was placed at each of 4 culvert locations connecting the impoundment to the estuary. Each culvert location consists of 1 flapgated culvert and 1 with slots for riserboards. Thus, 1 culvert was fished with a culvert trap and 1 remained unfished at each location. Piscivorous fish abundance (e.g. Lepisosteus platyrhincus, Sciaenops ocellatus, Elops saurus, and Cynoscion nebulosus) was determined with gill nets placed in the impoundment creek and ditch and deployed for 2 to $3 \mathrm{~h}$ between 17:00 and 21:00 h Eastern Standard Time. Piscivorous bird abundance (e.g. Egretta thula and Hydranassa tricolor) was determined from bird counts conducted throughout the entire impoundment between 07:00 and 10:00 h Eastern Standard Time. Basic assumptions of the biomass budget were: (1) estimated densities of fish and rates of migration and predation resulting from monthly sampling were representative of the entire month and (2) other disappearance $(O)$ includes mortality aside from predation by fish and birds. Note that data are available only for production as $P-O$, an underestimate of total production $(P)$ because the amount of $O$ is unknown.

Estimates of biomass budget parameters. Monthly fish population biomass was estimated from cast-net sampling (Table 1). Population biomass for the ditch and creek was estimated by multiplying fish densities within respective habitats by the area of each habitat. The area of the creek was determined from aerial photography by dividing the creek into small grids of known areas and counting the number of grids within the creek (area $=26195 \mathrm{~m}^{2}$ ). The area of the perimeter ditch was determined by multiplying the length of the ditch by its average width (area $=3633 \mathrm{~m}$ length $\times$ $10 \mathrm{~m}$ width $=36330 \mathrm{~m}^{2}$ ). Impoundment standing stock for the biomass budget was the sum of creek and ditch population biomass. Estimated population biomass was multiplied by $5(100 / 20)$ to correct for cast-net efficiency, which was estimated to be within a range of from 10 to $28 \%$ in gear-testing studies conducted in the study impoundment (Stevens 2006).

Monthly estimates for net fish ingress were calculated by multiplying hourly culvert averages (Table 1) by hours in the month, and by the number of open culverts. Because fished and unfished culverts did not significantly differ in catch (Stevens et al. 2006), average catch in the 4 fished culverts was assumed to represent the remaining unfished culverts. Net fish ingress values were multiplied by $6.7(100 / 15)$ to account for culvert-trap catch efficiency, which was estimated to be within a range of 15 to $20 \%$ in gear-testing studies conducted in a nearby impoundment (Stevens 2006).

To determine the daily consumption of marsh fishes by piscivorous fish, an estimate of impoundment fish abundance was needed. Good water clarity during April 2001 allowed for a count of Florida gar Lepisosteus platyrhincus, which remain close to the surface and are conspicuous. Counts of L. platyrhincus in a given area were extrapolated to the entire impoundment. A total of 28 Florida gar were counted along a stretch of perimeter ditch $\left(4150 \mathrm{~m}^{2}\right)$, resulting in a density of $6.7 \times 10^{-3}$ fish $\mathrm{m}^{-2}$. Multiplying this density by area of ditch and creek within the impoundment accessible to Florida gar results in an estimate of 332 Florida gar in the impoundment. The gill net catch immediately following the observation was 10.3 Florida gar per $10 \mathrm{~m}$ net $\mathrm{h}^{-1}$. The result of gill net catch per unit effort divided by total Florida gar abundance is 0.03 . Thus, the gill net catch per unit effort represents $3 \%$ of the impoundment population of Florida gar. Catch per unit effort data from gill nets (Table 1) were converted to impoundment fish population by multiplying by 30 . Using a conversion factor from this method, however, assumes that all other piscivorous fish species are caught similarly to L. platyrhincus in gill nets.

Daily prey consumption by piscivorous fishes was based upon published values for estuarine fishes (Table 2). Hunt (1960) and McGoogan \& Gatlin (1998) estimated prey consumption from feeding experiments. Buckel et al. (1999) estimated prey consumption from diet analyses, and Hartman \& Brandt (1995) and Hartman (2000) estimated prey consumption from both diet and observed growth rates. An estimate of $0.04 \mathrm{~g}$ wet prey $\mathrm{d}^{-1} \mathrm{~g}^{-1}$ predator body weight (intermediate among literature estimates) was used in the biomass budget. For each month, the estimated population biomass of piscivorous fishes ( $\mathrm{g}$ piscivorous fish per marsh) was multiplied by estimated consumption by piscivorous fishes and multiplied by the number of days in each month.

Bird consumption estimates used in the biomass budget were taken from published values (Table 3). Junor (1972) hand-reared piscivorous birds (darters, cormorants, and herons) and estimated daily prey consumption (g wet weight) by birds to be $16 \%$ of the bird's wet body weight. Kushlan (1978) summarized the relationship between bird size and prey consumption for wading birds, Walsberg (1983) summarized daily energy expenditure of free-living birds, and BirtFriesen et al. (1989) estimated field metabolism of freeliving seabirds using doubly labeled water and activity 
budgets. Average bird consumption per day was generated for each piscivorous species by substituting the weight of a typical adult bird into each of 4 equations (Table 3). These average bird consumption estimates were multiplied by average monthly bird abundance within the impoundment (Table 4) and multiplied by the number of days in each month.

Sensitivity analysis of biomass budget. An analysis was performed on all biomass-budget parameter estimates to determine the sensitivity of these parameters to the overall fish production estimate (total $\mathrm{g}$ fish per impoundment $\mathrm{yr}^{-1}$ ). Each parameter estimate was individually increased by $30 \%$ and also decreased by $30 \%$, and the production calculation was recomputed. The changed budget parameters included: creek fish density, ditch fish density, creek area, ditch area, cast-net gear efficiency, net fish ingress catch per unit effort, culverttrap gear efficiency, gill net catch per unit effort, conversion from gill net catch per unit effort to population estimate, daily consumption by piscivorous fish, bird abundance, and daily consumption by birds.

\section{RESULTS AND DISCUSSION}

The results of the production calculation using the biomass budget are given in Table 5, which includes monthly estimates for standing stock, consumption by

Table 2. Daily prey consumption estimates ( $\mathrm{g}$ wet prey consumed $\mathrm{g}^{-1}$ predator wet body weight $\mathrm{d}^{-1}$ ) reported for selected estuarine fishes

\begin{tabular}{|c|c|c|c|c|}
\hline Species & Common name & Age class & Prey consumption & Source \\
\hline Lepisosteus platyrhincus & Florida gar & Juvenile & 0.0281 & Hunt (1960) \\
\hline Cynoscion regalis & Weakfish & 1 & 0.051 & Hartman \& Brandt (1995) \\
\hline Cynoscion regalis & Weakfish & 2 & 0.036 & Hartman \& Brandt (1995) \\
\hline Pomatomus saltatrix & Bluefish & 0 & 0.048 & Hartman \& Brandt (1995) \\
\hline Pomatomus saltatrix & Bluefish & 1 & 0.043 & Hartman \& Brandt (1995) \\
\hline Pomatomus saltatrix & Bluefish & 2 & 0.037 & Hartman \& Brandt (1995) \\
\hline Sciaenops ocellatus & Red drum & Juvenile & $0.014-0.023$ & McGoogan \& Gatlin (1998) \\
\hline Pomatomus saltatrix & Bluefish & 0 & $0.04-0.12$ & Buckel et al. (1999) \\
\hline Morone saxatilis & Striped bass & 0 & $0.0326-0.0559$ & Hartman (2000) \\
\hline \multicolumn{3}{|l|}{ Average } & $0.037-0.049$ & \\
\hline
\end{tabular}

Table 3. Daily prey consumption estimates reported for piscivorous birds taken from published values. Conversions: assimilation efficiency $=0.80$ (for $\mathrm{kJ}$ energy expenditure to $\mathrm{kJ}$ prey intake), $1 \mathrm{~kJ}=0.23892 \mathrm{kcal}, 1 \mathrm{kcal}=0.833 \mathrm{~g}$ wet biomass

\begin{tabular}{|c|c|c|c|c|c|c|c|}
\hline \multirow[t]{2}{*}{ Species } & \multirow[t]{2}{*}{ Common name } & \multirow{2}{*}{$\begin{array}{l}\text { Weight }^{\mathrm{a}} \\
\text { (g) }\end{array}$} & \multicolumn{5}{|c|}{- Prey consumption (g wet weight prey $\mathrm{d}^{-1}$ ) } \\
\hline & & & $\begin{array}{c}\text { Junor } \\
(1972)^{\mathrm{b}}\end{array}$ & $\begin{array}{c}\text { Kushlan } \\
(1978)^{\mathrm{c}}\end{array}$ & $\begin{array}{l}\text { Walsberg } \\
{(1983)^{\mathrm{d}}}^{\text {W }}\end{array}$ & $\begin{array}{l}\text { Birt-Friesen } \\
\text { et al. }(1989)^{\mathrm{e}}\end{array}$ & Average \\
\hline Pelecanus occidentalis & Brown pelican & 3723 & 596 & 614 & 385 & 632 & 557 \\
\hline Mycteria americana & Wood stork & 2724 & 436 & 455 & 318 & 504 & 428 \\
\hline Ardea herodias & Great blue heron & 2588 & 414 & 433 & 309 & 485 & 410 \\
\hline Phalacrocorax auritus & Double-crested cormorant & 1816 & 291 & 308 & 249 & 375 & 306 \\
\hline Anhinga anhinga & American anhinga & 1226 & 196 & 211 & 196 & 282 & 221 \\
\hline Casmerodius albus & Great egret & 908 & 145 & 158 & 163 & 227 & 173 \\
\hline Nycticorax nycticorax & Black-crowned night heron & 863 & 138 & 151 & 158 & 218 & 166 \\
\hline Dichromanassa rufescens & Reddish egret & 454 & 73 & 81 & 107 & 137 & 99 \\
\hline Hydranassa tricolor & Louisiana heron & 409 & 65 & 74 & 100 & 127 & 92 \\
\hline Egretta thula & Snowy egret & 363 & 58 & 66 & 93 & 116 & 83 \\
\hline Florida caerulea & Little blue heron & 363 & 58 & 66 & 93 & 116 & 83 \\
\hline Butorides striatus & Green heron & 227 & 36 & 42 & 70 & 83 & 58 \\
\hline Megaceryle alcyon & Belted kingfisher & 136 & 22 & 26 & 51 & 57 & 39 \\
\hline $\begin{array}{l}{ }^{\mathrm{a}} \text { Wet weight of adult birds } \\
{ }^{\mathrm{b}} y=16 \% \text { weight of bird d } \\
{ }^{\mathrm{c}} \log y=0.96 \log x-0.64, \mathrm{w} \\
{ }^{\mathrm{d}} \ln y=\ln 12.84+0.61 \ln M \\
{ }^{\mathrm{e}} \log y=2.99+0.727 \log x\end{array}$ & $\begin{array}{l}\text { (Terres 1980) } \\
1 \text {, where } y=\mathrm{g} \text { wet weight pr } \\
\text { iere } y=\mathrm{g} \text { wet weight prey } \mathrm{d}^{-} \\
\text {vhere } y=\mathrm{kJ} \text { prey } \mathrm{d}^{-1} \text {, and } M \\
\text { there } y=\mathrm{kJ} \text { energy expendit }\end{array}$ & $\begin{array}{l}\text { ey } \mathrm{d}^{-1} \\
1 \text {, and } x= \\
=\text { weight } \\
\text { ure } \mathrm{d}^{-1} \text {, an }\end{array}$ & $\begin{array}{l}\text { ght of bir } \\
\text { ird }(\mathrm{g}) \\
=\text { weight }\end{array}$ & $\begin{array}{l}\text { rd }(g) \\
\text { t of bird }\end{array}$ & & & \\
\hline
\end{tabular}


Table 4. Estimates of monthly piscivorous bird abundance (no. birds per impoundment) in Impoundment C20C. Data are from Stevens et al. (2006). Bird abundance was estimated by averaging bird counts within the impoundment ( $\mathrm{n}=2$ bird counts mo ${ }^{-1}$ )

\begin{tabular}{|c|c|c|c|c|c|c|c|c|c|c|c|c|c|}
\hline \multirow{2}{*}{ Species } & \multirow{2}{*}{ Common name } & \multicolumn{6}{|c|}{2000} & \multicolumn{6}{|c|}{2001} \\
\hline & & Jul & Aug & Sep & Oct & Nov & Dec & Jan & Feb & Mar & Apr & May & Jun \\
\hline Pelecanus occidentalis & Brown pelican & & & & & & & & 0.5 & & & & \\
\hline Mycteria americana & Wood stork & 3 & & & 8 & 1.5 & & 1.5 & & & & & \\
\hline Ardea herodias & Great blue heron & 1.5 & 1 & 0.5 & 2.5 & 1.5 & & 0.5 & 1 & 0.5 & & & 1.5 \\
\hline Phalacrocorax auritus & Double-crested cormorant & 0.5 & & & 0.5 & 0.5 & & & & & & & \\
\hline Anhinga anhinga & American anhinga & 0.5 & 0.5 & 2 & & & 1 & 0.5 & 1 & & 0.5 & 0.5 & \\
\hline Casmerodius albus & Great egret & 3 & 20 & 2.5 & 3.5 & 0.5 & 1 & 6 & 2 & & & 0.5 & \\
\hline Nycticorax nycticorax & Black-crowned night heron & & & & & 2 & & & & & & & \\
\hline Dichromanassa rufescens & Reddish egret & 0.5 & 4.5 & & & & & & & & & & \\
\hline Hydranassa tricolor & Louisiana heron & 4 & 24 & 1 & 1.5 & & 5.5 & 5 & 1.5 & 2 & 0.5 & 1.5 & 1.5 \\
\hline Egretta thula & Snowy egret & 0.5 & 94.5 & 1 & 3.5 & & & 16 & 1 & & & & \\
\hline Florida caerulea & Little blue heron & & & & & & 0.5 & & & & 0.5 & & \\
\hline Butorides striatus & Green heron & 2 & 3 & 1 & & 0.5 & 0.5 & & & & 1 & 1.5 & 2 \\
\hline Megaceryle alcyon & Belted kingfisher & & 1 & & 0.5 & 1.5 & 1 & 1.5 & 1 & & 0.5 & & \\
\hline
\end{tabular}

piscivorous fishes and birds, and net fish ingress. Over the study period, 1.6 metric tons of saltmarsh fishes were consumed by piscivorous fishes, 1.1 metric tons were consumed by birds, and 2.4 metric tons were exported directly from the saltmarsh to the estuary. On the basis of saltmarsh area (entire impoundment), direct export was about $5.6 \mathrm{~g}$ fish $\mathrm{m}^{-2}$ marsh $\mathrm{yr}^{-1}$ (2390 kg fish $\mathrm{yr}^{-1} / 4.27 \times 10^{5} \mathrm{~m}^{-2}$ marsh).

Table 5. Fish production (kg fish per impoundment $\mathrm{mo}^{-1}$ ) in Impoundment $\mathrm{C} 20 \mathrm{C}$, estimated from biomass budget: $P-O=$ $\Delta X+Y_{\mathrm{f}}+Y_{\mathrm{b}}-M$, where $P$ : production; $O$ : other disappearance; $X$ : standing stock; $Y_{\mathrm{f}}$ : yield to piscivorous fish; $Y_{\mathrm{b}}$ : yield to piscivorous birds and $M$ : net fish ingress

\begin{tabular}{|c|c|c|c|c|c|}
\hline & $\Delta X$ & $Y_{\mathrm{f}}$ & $Y_{\mathrm{b}}$ & $M$ & $P-O$ \\
\hline Jul & 587 & 44 & 101 & 622 & 109 \\
\hline Aug & -1040 & 45 & 456 & -124 & -415 \\
\hline Sep & 534 & 344 & 39 & 013 & 904 \\
\hline Oct & -223 & 79 & 175 & -325 & 356 \\
\hline Nov & 3458 & 46 & 58 & 1 & 3561 \\
\hline Dec & 4711 & 118 & 31 & -240 & 5100 \\
\hline Jan & -3475 & 84 & 119 & -1010 & -2263 \\
\hline Feb & -3605 & 25 & 42 & -413 & -3124 \\
\hline Mar & 976 & 51 & 12 & -249 & 1288 \\
\hline Apr & 684 & 251 & 8 & -124 & 1067 \\
\hline May & -257 & 24 & 13 & -33 & -188 \\
\hline Jun & 2674 & 512 & 26 & -508 & 3720 \\
\hline Total $^{\mathrm{a}}$ & 5025 & 1620 & 1080 & -2390 & 10117 \\
\hline$\%$ production $^{\mathrm{b}}$ & 38 & 12 & 8 & 18 & \\
\hline \multicolumn{6}{|c|}{$\begin{array}{l}\text { a Over the course of the study, the effects of marsh surface } \\
\text { migrations cancel out (see 'Discussion'). Assuming nega- } \\
\text { tive production during February }(-3124 \mathrm{~kg} \text { fish per } \\
\text { impoundment } \mathrm{yr}^{-1} \text { ) is attributable to } O \text { and } O \text { is negligi- } \\
\text { ble aside from February, impoundment fish production is } \\
\sim 13241 \mathrm{~kg} \mathrm{yr}^{-1} \\
\text { b\% production for } O \text { is } 24 \%\end{array}$} \\
\hline
\end{tabular}

The sensitivity analysis of the biomass budget showed that the model is relatively robust. Biomass budget output (production estimate $P-O$ ) did not change by $>15 \%$ when changes to input parameters were varied by $30 \%$. Manipulation of cast-net gear efficiency resulted in the greatest changes to output. For example, if cast-net gear efficiency was 15 or $29 \%$ instead of the estimated $20 \%$, then estimated fish production $(P-O)$ would change from 10117 to 8609 or $11625 \mathrm{~kg}$ fish per impoundment $\mathrm{yr}^{-1}$ (output changes of $15 \%$ ). Changes to creek fish density or creek area resulted in output changes of $13 \%$, and changes to ditch fish density or ditch area resulted in output changes of $2 \%$. Manipulation of culvert-trap catch per unit effort or efficiency parameters resulted in changes to output of $7 \%$. For example, if culvert-trap efficiency was 11 or $21 \%$ instead of the estimated $15 \%$, then estimated fish production $(P-O)$ from the biomass budget would change by $7 \%$. Manipulation of parameters associated with fish and bird consumption resulted in changes to output of 3 to $5 \%$. For example, if the conversion from gill-net catch per unit effort to impoundment piscivore population was 21 or 39 rather than the estimated 30 (gill net catch per unit effort represents 2.6 or $4.8 \%$ of the impoundment piscivore population rather than $3 \%$ ), then estimated fish production would change by $5 \%$.

Assuming that standing stock, consumption, and migration estimates (based on direct sampling) used in the fish biomass budget were accurate, then negative values resulting from the biomass budget were attributable to mortality (other than predation) and marsh surface migrations. Negative production $(P-O)$ values in July and May were probably the result of fish migrating from the ditch and creek (where standing stock is measured) to the marsh surface, because water 


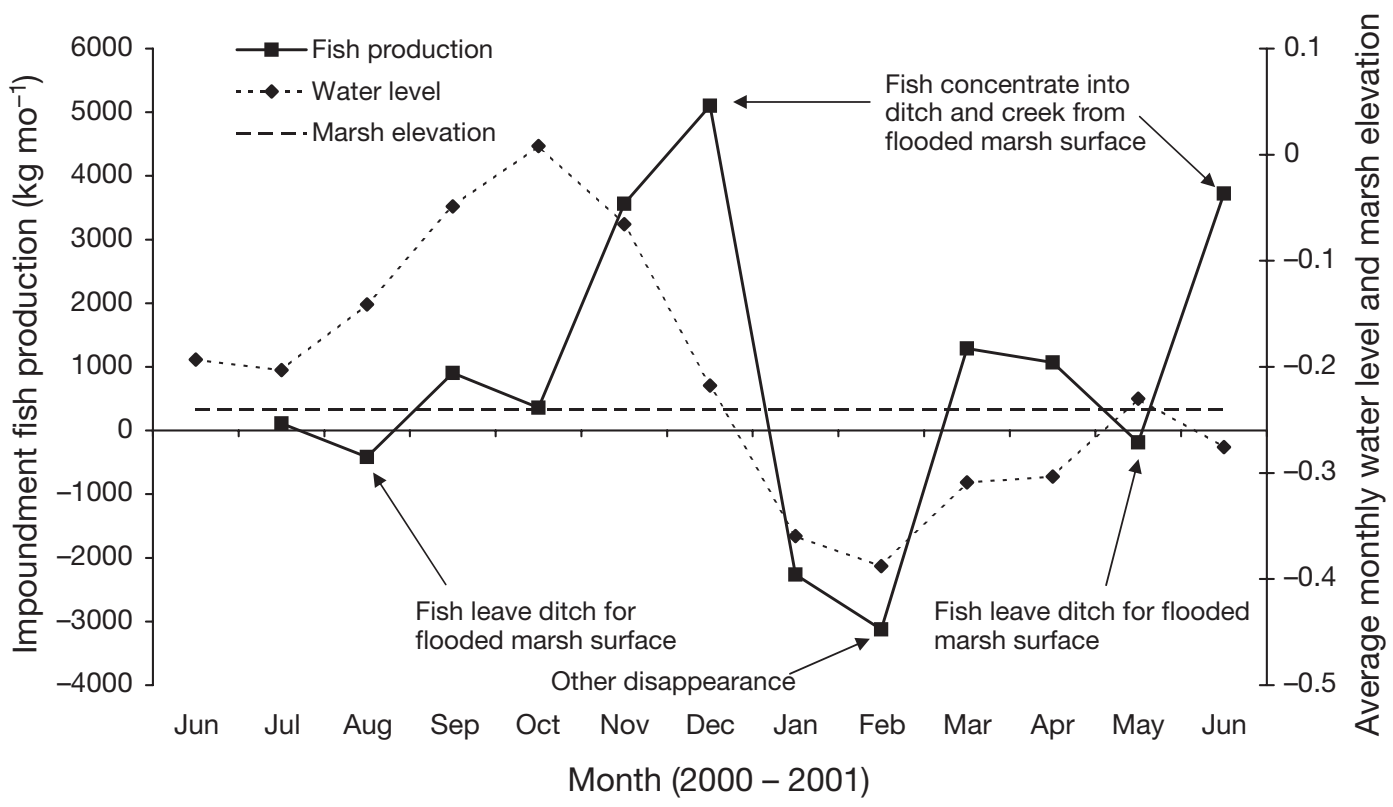

Fig. 2. Estimated fish production $\left(\mathrm{kg} \mathrm{mo}^{-1}\right)$, average monthly water level $(\mathrm{m})$, and marsh elevation $(\mathrm{m})$ in Impoundment C20C. Water level and marsh elevation were surveyed with respect to the 1988 North American Vertical Datum (NAVD 88) (Stevens et al. 2006)

levels exceeded the threshold of marsh flooding (Fig. 2). High production $(P-O)$ values in December and June probably resulted from fish migrating from the marsh surface back to the ditch and creek as water drained the marsh (Fig. 2). Over the long run, marsh surface migrations should cancel. For example, fish leaving the ditch and creek to the marsh surface in July may result in negative production values, but when the fish return to the ditch and creek in December, this production is added back in addition to the fish production (and bird consumption) that occurred on the marsh surface. Thus, correcting for marsh surface migrations is not necessary to estimate total production during the study.

Negative production also occurs in February, which cannot be explained by marsh surface migrations because water levels remained low through the following month. This negative production occurred following a month where fish densities were the highest ( $\sim 35$ fish $\mathrm{m}^{-2}$ ) and freezes occurred (Stevens et al. 2006). If the negative fish production is attributable to mortality caused by freezes or density-dependent effects, then this other disappearance $(O)$ should be added to production. Assuming $O$ is negligible aside from the February mortality, total fish production in the study impoundment was estimated at $13241 \mathrm{~kg}$ fish per impoundment $\mathrm{yr}^{-1}$ (Table 5). On the basis of saltmarsh area (combining impoundment fish habitats: ditches, creeks, and marsh surface), production for the study impoundment was $31.0 \mathrm{~g}$ fish $\mathrm{m}^{-2} \mathrm{yr}^{-1}\left(13.241 \times 10^{6} \mathrm{~g}\right.$ fish per impoundment $\mathrm{yr}^{-1} / 4.27 \times 10^{5} \mathrm{~m}^{2}$ per impoundment).
Fish production estimated from the biomass budget is within the range of published estimates of estuarine fish communities (Table 6). Estimates range from $2.6 \mathrm{~g}$ fish $\mathrm{m}^{-2} \mathrm{yr}^{-1}$ for seagrass fish communities in Mosquito Lagoon, Florida, to well over $30 \mathrm{~g}$ fish $\mathrm{m}^{-2} \mathrm{yr}^{-1}$ for coastal and estuarine fish communities in Mexico, Louisiana, and California. Fish production calculated from Ricker's equations for the study impoundment

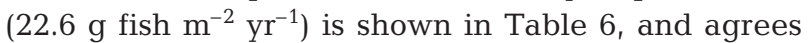
relatively well with the estimate from the biomass budget.

Closed saltmarsh impoundments (no estuarine connectivity), located only 8 and $28 \mathrm{~km}$ to the north of the study impoundment, were as much as $17 \mathrm{~g}_{\text {fish } \mathrm{m}^{-2}}$ $\mathrm{yr}^{-1}$ more productive than the study impoundment (Schooley 1980, our Table 6). Studies comparing open and closed impoundments in the Indian River Lagoon, Florida, have shown that resident fish densities are much higher in closed impoundments (Rey et al. 1990, Taylor et al. 1998). Greater standing stock of resident fishes in closed systems may result from prevention of resident fish migration to the estuary and reduction in transient estuarine predators. Another explanation for greater standing stock of resident fishes is higher fish production rates due to greater food resources (e.g. microalgae or mosquito larvae), greater food quality, or greater access to food as a result of longer flooding. Although fish production may be higher in closed impoundments, the biomass is trapped within the closed system, except for transfer by bird predation. The trapping of fish biomass and manipulation of 
Table 6. Estimates of fish production $\left(\mathrm{g} \mathrm{m}^{-2} \mathrm{yr}^{-1}\right)$ among estuarine communities. References are from Table 10.3 in Day et al. (1989), except Schooley (1980), Adams (1976), and Allen (1982)

\begin{tabular}{|llcl|}
\hline Fish community & Location & Fish production & Source \\
\hline Seagrass & Mosquito Lagoon, Florida & $2.6^{\mathrm{a}}$ & Schooley (1980) \\
Estuarine & Laguna Madre, Texas & $12.1-57.6^{\mathrm{a}}$ & Hellier (1962), Jones et al. (1963) \\
Seagrass & North Carolina & $18.4^{\mathrm{a}}$ & Adams (1976) \\
Saltmarsh & Banana Creek, Florida & $22.6^{\mathrm{b}}, 31.0^{\mathrm{c}}$ & Present study \\
Lagoon & Terminos Lagoon, Mexico & $20.0^{\mathrm{a}}$ & Yáñez-Arancibia \& Lara Domínguez (1983) \\
Coastal lagoon & Cuba & $22.0-27.6^{\mathrm{a}}$ & Holcik (1970) \\
Coastal lagoon & Mexico, Pacific coast & $24.6-66.7^{\mathrm{a}}$ & Yáñez-Arancibia (1978) \\
Coastal & Mexico, Pacific coast & $34.5^{\mathrm{a}}$ & Warburton (1979) \\
Estuarine & Barataria Bay, Louisiana & $35.0-72.8^{\mathrm{a}}$ & Day et al. (1973), Wagner (1973) \\
Littoral zone of tidal marsh & California & $37.4^{\mathrm{a}}$ & Allen (1982) \\
Saltmarsh impoundments & Mosquito Lagoon, Florida & $38.8-59.2^{\mathrm{a}}$ & Schooley (1980) \\
& & $31.5-40.0^{\mathrm{b}}$ & \\
${ }^{\mathrm{a} B a s e d}$ on summation of production estimates for component species & \\
based on production equations in Ricker (1946) modified by Allen (1950) and Chapman (1978), but substituting monthly \\
biomass of whole community rather than summation of species & \\
\multicolumn{2}{c}{ cBased on fish biomass budget: annual fish production/area of saltmarsh } & \\
\hline
\end{tabular}

water levels to provide optimal foraging depths to wading birds may explain why managed impoundments are successful at providing feeding opportunities to avian wildlife (e.g. Smith \& Breininger 1995).

The fate of fish production within the study impoundment is shown in Fig. 3 (results derived from Table 5). Overall mortality by biomass (combining other disappearance and consumption by fishes and birds) was $44 \% \mathrm{yr}^{-1}$. For comparison, mortality rates were estimated at 0.023 to $0.041 \% \mathrm{~d}^{-1}$ ( 8.4 to $15.0 \%$ $\mathrm{yr}^{-1}$ ) for Leiostomus xanthurus (e.g. Currin et al. 1984), 23 to $61 \%$ (2 wk mortality) for Penaeus aztecus

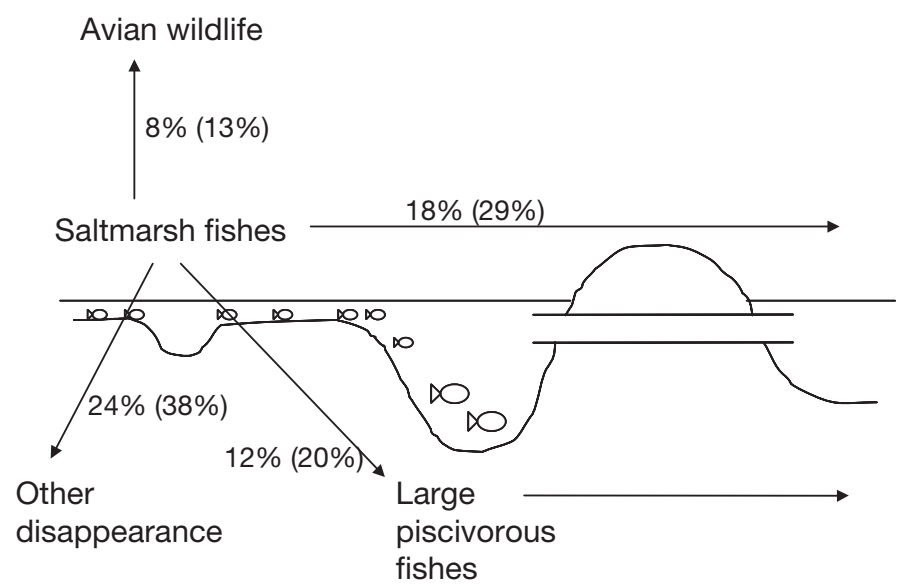

Fig. 3. Fate of fish production in Impoundment C20C. The remaining $38 \%$ of fish production was attributable to changes in standing stock (i.e. biomass accumulated during the study period). This surplus standing stock may later enter one or several of the above pathways. Numbers in parentheses show percentage of production if the accumulated biomass is prorated among the pathways
(Minello et al. 1989), and as high as $50 \% \mathrm{yr}^{-1}$ for mummichog Fundulus heteroclitus (Meredith \& Lotrich 1979). Note that $38 \%$ of fish production was attributable to changes in standing stock (Fig. 3). This means that fish standing stock accumulated during the study period. This fish production may enter one of the pathways shown in Fig. 3 (emigration, consumption, or other disappearance) sometime in the future. If the fish production accumulated as standing stock is prorated among the pathways, then an additional $8 \%$ of fish production will be consumed by piscivorous fish, another $5 \%$ will be consumed by piscivorous birds, an additional $14 \%$ will be lost to other disappearance, and another $11 \%$ will emigrate to the estuary.

The pathway of consumption by piscivorous fishes shown in Fig. 3 represents the trophic relay. Assuming a $10 \%$ energy transfer for each increase in trophic level, piscivorous fishes potentially move 1.2 to $2.0 \%$ of fish production to the adjacent estuary after consuming 12 to $20 \%$ of saltmarsh fish production. Consumption by piscivorous fish within the impoundment was greatest during August through October, when large juvenile Sciaenops ocellatus and Cynoscion nebulosus were abundant within the impoundment, and during April and June when Lepisosteus platyrhincus were abundant, coincident with low-salinity pulses (Stevens et al. 2006). Thus, the movement of marsh production to the estuary by trophic relay was greatest during high water level, when water conditions were most favorable for large piscivorous fish (i.e. cool temperatures and high dissolved oxygen), and during late spring and early summer, when low salinity allowed opportunistic $L$. platyrhincus to take advantage of favorable water conditions and abundant food within the impoundment. 
Direct export of fish biomass was estimated to be 18 to $29 \%$ (Fig. 3). The greatest export occurred as the water level receded during winter, concentrating resident fishes in ditches and creeks (Stevens et al. 2006). The high value associated with direct fish biomass export may be unique to seasonally flooded marshes, because a long period of low water level may prompt fishes to migrate from the impoundment in response to overcrowding (Stevens et al. 2006). Interestingly, piscivorous fish abundance was low during low winter water level and temperature, allowing resident fishes to leave the impoundment with minimum predation by large fishes.

The combined export of fish biomass from impoundment to estuary (combining direct export and movement by piscivorous fish consumption) was 19 to $31 \%$. In closed impoundments in Mosquito Lagoon, the transfer of net primary marsh production to fish production (fish production/net marsh production) was estimated at $6.5 \%$ (Schooley 1980). Multiplying this transfer ratio $(6.5 \%)$ by exported fish production (19 to $31 \%$ ), the saltmarsh primary production that moved to the estuary in the tissues of fish was about 1 to $2 \%$. For comparison, the quantity of marsh primary production exported as detritus in a similar high-elevation marsh in Texas (dominated by Distichlis spicata) was 3 to $5 \%$ (Borey et al. 1983). Thus, the movement of saltmarsh production by fishes may be similar to that exported as detritus.

This study is, to our knowledge, the first to quantify the yield of estuarine fishes to predators and direct export to the estuary and to estimate movement of saltmarsh primary production to the estuary by fishes. Of equal importance in evaluating the significance of saltmarsh export to the estuary is the quality of exported products. Qualitative factors include energetic content, protein content, and nutrient content of food sources. Small juvenile transient fishes incorporate marsh foods into their tissues as they consume detritus and algae from saltmarsh creeks. Residents are able to cover the shallow marsh surface, thereby consuming marsh foods that would otherwise be difficult for transient fishes to access (Werme 1981). The quality of these marsh foods is concentrated as they are incorporated into the tissues of fish. For example, detritus contains about 1 to $2 \%$ nitrogen (Day et al. 1989), whereas fish tissue contains $>10 \%$ nitrogen (Deegan 1993). In addition, fish tissue has concentrated levels of protein and lipids relative to detritus, and higher energetic content. From the perspective of large estuarine fishes and mammals, the quality of resident and small transient fish tissues is readily useable. Thus, marsh fishes not only move saltmarsh production to the estuary, but also convert low-quality saltmarsh foods to higher quality vagile biomass, providing an efficient link between saltmarshes and higher trophic carnivores in the adjacent estuary.

The movement of saltmarsh production to the estuary by fishes quantified in this study illustrates the value of saltmarsh-estuarine connectivity, because the export of resident marsh fishes may represent a substantial food source for estuarine predators. For example, when almost all Indian River Lagoon saltmarshes were impounded (with no connection) during the 1970s, marsh fish production was trapped behind a system of dikes, and was unavailable for consumption by estuarine predators. At $>16200$ ha of saltmarshes impounded (Brockmeyer et al. 1997), lost fish biomass to the estuary may have totaled $>840$ metric tons $\mathrm{yr}^{-1}$ (if pre-impoundment saltmarshes exported fish biomass at the magnitude of the study impoundment, $5.2 \mathrm{~g}$ fish $\mathrm{m}^{-2}$ marsh). If resident fish export from other reconnected saltmarsh impoundments in the vicinity is similar to that of the study impoundment, then resource managers can expect an export of 5.2 metric tons of small marsh fish annually for every 100 ha of impounded marsh reconnected. Although the numbers associated with the export of fish biomass from these seasonally flooded saltmarshes seem colossal, it is not known whether the exported biomass can actually enhance the diets of estuarine predators and represent an ecologically significant source of food compared to what is already present in the estuary. The next logical step in expanding upon the knowledge obtained during this study is to use stable isotope analysis, or other analytical research tools, to directly test the value of saltmarsh fishes to the diet of estuarine predators in areas where saltmarshes have been reconnected.

Acknowledgements. Research was supported by the US Geological Survey Coastal Restoration Initiative. The refuge managers and staff at Merritt Island National Wildlife Refuge provided access to field sites and knowledge of impoundment ecology. T. Crisman and F. Percival provided constructive and helpful comments in the development of the manuscript.

\section{LITERATURE CITED}

Adams SM (1976) The ecology of eelgrass, Zostera marina (L.), fish communities. II. Functional analysis. J Exp Mar Biol Ecol 22:293-311

Allen KR (1950) The computation of production in fish populations. NZ Sci Rev 8:89

Allen LG (1982) Seasonal abundance, composition, and productivity of the littoral fish assemblage in upper Newport Bay, California. Fish Bull 80:769-790

Birt-Friesen VL, Montevecchi WA, Cairns DK, Macko SA (1989) Activity-specific metabolic rates of free-living northern gannets and other seabirds. Ecology 70:357-367

Boesch DF, Turner RE (1984) Dependence of fishery species on salt marshes: the role of food and refuge. Estuaries 7: $460-468$ 
Borey RB, Harcombe PA, Fisher FM (1983) Water and organic carbon fluxes from an irregularly flooded brackish marsh on the upper Texas coast, USA. Estuar Coast Shelf Sci 16: 379-402

Brockmeyer RE, Rey JR, Virnstein RW, Gilmore RG, Earnest L (1997) Rehabilitation of impounded estuarine wetlands by hydrologic reconnection to the Indian River Lagoon, Florida (USA). Wetl Ecol Manag 4:93-109

Buckel JA, Fogarty MJ, Conover DO (1999) Foraging habits of bluefish, Pomatomus saltatrix, on the U.S. east coast continental shelf. Fish Bull 97:758-775

Chapman DW (1978) Production in fish populations. In: Gerking SD (ed) Ecology of freshwater fish production. John Wiley \& Sons, New York, p 5-25

Currin BM, Reed JP, Miller JM (1984) Growth, predation, food consumption, and mortality of juvenile spot and croaker: a comparison of tidal and nontidal nursery areas. Estuaries 7:451-459

Dame RF (1994) The net flux of materials between marshestuarine systems and the sea: the Atlantic coast of the United States. In: Mitsch WJ (ed) Global wetlands: old world and new. Elsevier, Amsterdam, p 295-302

Dame RF, Spurrier JD, Williams TM, Kjerfve B and 5 others (1991) Annual material processing by a salt marshestuarine basin in South Carolina. Mar Ecol Prog Ser 72: 153-166

Day JW, Hall CAS, Kemp WM, Yanez-Arancibia A (1989) Estuarine ecology. John Wiley \& Sons, New York

Deegan LA (1993) Nutrient and energy transport between estuaries and coastal marine ecosystems by fish migration. Can J Fish Aquat Sci 50:74-79

Haines EB (1979) Interactions between Georgia salt marshes and coastal waters: a changing paradigm. In: Haines EB, Livingston RJ (eds) Ecological processes in coastal and marine systems. Plenum, New York, p 35-46

Haines EB, Montague CL (1979) Food sources of estuarine invertebrates analyzed using ${ }^{13} \mathrm{C} /{ }^{12} \mathrm{C}$ ratios. Ecology 60 : 48-56

Haines EB, Chalmers A, Hanson R, Sherr B (1977) Nitrogen pools and fluxes in a Georgia salt marsh. In: Wiley M (ed) Estuarine processes, Vol 2. Academic Press, New York, p 241-254

Hartman KJ (2000) Variability in daily ration estimates of Age-0 striped bass in the Chesapeake Bay. Trans Am Fish Soc 129:1181-1186

Hartman KJ, Brandt SB (1995) Predatory demand and impact of striped bass, bluefish, and weakfish in the Chesapeake Bay: applications of bioenergetics models. Can J Fish Aquat Sci 52:1667-1687

Heinle DR, Flemer SA (1976) Flows of material between poorly flooded tidal marshes and an estuary. Mar Biol 35: 359-373

Hellier TR (1962) Fish production and biomass studies in relation to photosynthesis in the Laguna Madre of Texas. Publ Inst Mar Sci Univ Texas 8:212-215

Herke WH, Knudsen EE, Knudsen PA, Rogers BD (1992) Effects of semi-impoundment of Louisiana marsh on fish and crustacean nursery use and export. N Am J Fish Manage 12:151-160

Holcik J (1970) Standing crop, abundance, production, and some ecological aspects of fish population in some waters of Cuba. Vestn Cs Spol Zool (Acta Zoc Zool Bohemuslov) 34:184-201

Hopkinson CS, Schubauer JP (1984) Static and dynamic aspects of nitrogen cycling in the graminiod Spartina alterniflora. Ecology 65:961-969

Hunt BP (1960) Digestion rate and food consumption of
Florida gar, warmouth, and largemouth bass. Trans Am Fish Soc 89:206-211

Jones R, Ogletree W, Thompson J, Flennilsen W (1963) Helicopter borne purse net for population sampling of shallow marine bays. Publ Inst Mar Sci Univ Texas 9:1-6

Junor FJR (1972) Estimation of the daily food intake of piscivorous birds. Ostrich 43:193-205

Kaplan W, Valiela I, Teal JM (1979) Denitrification in a salt marsh ecosystem. Limnol Oceanogr 24:726-734

Kneib RT (1997) The role of tidal marshes in the ecology of estuarine nekton. Oceanogr Mar Biol Annu Rev 35: $163-220$

Kushlan JA (1978) Feeding ecology of wading birds. In: Sprunt AI, Ogden JC, Winckler S (eds) Wading birds. National Audubon Society, New York, p 249-298

Marinucci AC (1982) Trophic importance of Spartina alterniflora production and decomposition to the marshestuarine ecosystem. Biol Conserv 22:35-58

McGoogan BB, Gatlin DMI (1998) Metabolic requirements of red drum, Sciaenops ocellatus, for protein and energy based on weight gain and body composition. J Nutr 128: $123-129$

Meredith WH, Lotrich VA (1979) Production dynamics of a tidal creek population of Fundulus heteroclitus (Linnaeus). Estuar Coast Shelf Sci 8:99-118

Minello TJ, Zimmerman RJ, Martinez EX (1989) Mortality of young brown shrimp Penaeus aztecus in estuarine nurseries. Trans Am Fish Soc 118:693-708

Mitsch WJ, Gosselink JG (1993) Wetlands, 2nd edn. Van Nostrand Reinhold, New York

Montague CL, Odum HT (1997) The intertidal marshes of Florida's Gulf Coast. In: Coultas CL, Hsieh YP (eds) Ecology and management of tidal marshes: a model from the Gulf of Mexico. St. Lucie Press, Delray Beach, p 1-33

Montague CL, Wiegert RG (1990) Salt marshes. In: Myers RL, Ewel JJ (eds) Ecosystems of Florida. University of Central Florida Press, Orlando, p 481-516

Montague CL, Bunker SM, Haines EB, Pace ML, Wetzel RL (1981) Aquatic macroconsumers. In: Pomeroy LR, Wiegert RG (eds) The ecology of a salt marsh. Springer-Verlag, New York, p 69-85

Montague CL, Zale AV, Percival HF (1987) Ecological effects of coastal marsh impoundments: a review. Environ Manag 11:743-756

Nixon SW (1980) Between coastal marshes and coastal waters-a review of twenty years of speculation and research on the role of salt marshes in estuarine productivity and water chemistry. In: Hamilton P, MacDonald KB (eds) Estuarine and wetland processes. Plenum, New York, p 69-85

Odum WE, de la Cruz AA (1967) Particulate organic detritus in a Georgia salt marsh-estuarine ecosystem. In: Lauff GH (ed) Estuaries. Publication No. 83, American Association for the Advancement of Science, Washington, DC, p 383-388

Rey JR, Shaffer J, Tremain D, Crossman RA, Kain T (1990) Effects of re-establishing tidal connections in two impounded subtropical marshes on fishes and physical conditions. Wetlands 10:27-45

Ricker WE (1946) Production and utilization of fish populations. Ecol Monogr 16:374-391

Schooley JK (1980) The structure and function of warm temperate estuarine fish communities. PhD dissertation, University of Florida, Gainesville

Smith RB, Breininger DR (1995) Wading bird populations of the Kennedy Space Center. Bull Mar Sci 57:230-236

Stevens PW (2006) Sampling fish communities in saltmarsh 
impoundments in the northern Indian River Lagoon, Florida: cast net and culvert trap gear testing. Fla Sci 69: 135-147

Stevens PW, Montague CL, Sulak KJ (2006) Patterns of fish use and piscivore abundance within a reconnected saltmarsh impoundment in the northern Indian River Lagoon, Florida. Wetl Ecol Manag 14:147-166

Taylor DI, Allanson BR (1995) Organic carbon fluxes between a high marsh and estuary, and the inapplicablity of the outwelling hypothesis. Mar Ecol Prog Ser 120:263-270

Taylor DS, Poulakis GR, Kupschus SR, Faunce CH (1998) Estuarine reconnection of an impounded mangrove salt marsh in the Indian River Lagoon, Florida: short-term changes in fauna. Mangroves Salt Marshes 2:29-36

Teal JM (1962) Energy flow in the salt marsh ecosystem of Georgia. Ecology 43:614-624

Terres JK (1980) The Audobon Society encyclopedia of North American birds. Alfred A Knopf, New York

Valiela I, Teal JM (1979) The nitrogen budget of a salt marsh ecosystem. Nature 280:652-656

Valiela I, Wright JM, Teal JM, Volkmann SB (1977) Growth, production, and energy transformations in the salt-marsh killifish Fundulus heteroclitus. Mar Biol 40:135-144

Wagner P (1973) Seasonal biomass, abundance, and distribution of estuarine dependent fishes in the Caminada Bay system of Louisiana. PhD dissertation, Louisiana State University, Baton Rouge, LA

Walsberg GE (1983) Avian ecological energetics. In: Farner DS, King JR, Parkes KC (eds) Avian biology, Vol VII. Academic Press, New York, p 161-212

Editorial responsibility: Victor de Jonge (Contributing Editor), Haren, The Netherlands
Warburton K (1979) Growth and production of some important species of fish in a Mexican coastal lagoon system. J Fish Biol 14:449-464

Weinstein MP (1983) Population dynamics of an estuarinedependent fish, the spot (Leiostomus xanthurus), along a tidal creek-seagrass meadow coenocline. Can J Fish Aquat Sci 40:1633-1638

Welsh BL (1975) The role of grass shrimp, Palaemonetes pugio, in a tidal marsh ecosystem. Ecology 56:513-530

Werme CE (1981) Resource partitioning in a salt marsh fish community. PhD dissertation, Boston University, MA

Wiegert RG, Christian RR, Gallagher JL, Hall JR, Jones RDH, Wetzel RL (1975) A preliminary ecosystem model of coastal Georgia Spartina marsh. In: Cronin LE (eds) Estuarine research, Vol 1. Academic Press, New York, p 583-601

Williams TM, Wolaver TG, Dame RF, Spurrier JD (1992) The Bly Creek ecosystem study-organic carbon transport within a euhaline salt marsh basin, North Inlet, South Carolina. J Exp Mar Biol Ecol 163:125-139

Yáñez-Arancibia A (1978) Taxonomy, ecology and structure of fish communities in coastal lagoons with ephemeral inlets on the Pacific Coast of Mexico. Centro Cienc del Mar y Limnol Univ Nal Auton Mexico Publ Esp 2:1-306

Yáñez-Arancibia A, Lara-Domínguez AL (1983) Environmental dynamic of Estero Pargo Inlet and structure of fish communities in daily and seasonal changes in Rhizophora mangle/Thalassia testudinum habitats (Terminos Lagoon, southern Gulf of Mexico). An Inst Cienc del Mar y Limnol Univ Nal Auton Mexico 10:85-116

Submitted: April 24, 2003; Accepted: May 1, 2006 Proofs received from author(s): November 14, 2006 